Annals of Warsaw University of Life Sciences - SGGW

Land Reclamation No 42 (1), 2010: 93-104

(Ann. Warsaw Univ. of Life Sci. - SGGW, Land Reclam. 42 (1), 2010)

\title{
Basement of the alluvia influence on the channel pattern in example of selected reach of the Pilica River
}

\author{
TOMASZ FALKOWSKI \\ Department of Geotechnical Engineering, Warsaw University of Life Sciences - SGGW
}

\begin{abstract}
Basement of the alluvia influence on the channel pattern in example of selected reach of the Pilica River. The type of the channel pattern is being considered as indicative element of the fluvial environment, especially for lowland, mature rivers. Investigations carried out in the Pilica River valley (example of such river) between Inowłódz and Domaniewice (grant no 2P04E 069 29, Ministry of Science) have shown that morphological features of the valley bottom (channel zone, as well as flood terrace) depends not only on river regime, but also on channel zone geological setting. Elements of the Pilica valley geology influencing on fluvial processes are protrusions of alluvia basement composed of deposits resistant to erosion, crop out in the channel zone.
\end{abstract}

Key words: channel pattern, alluvia basement, erosion resistant deposits.

\section{INTRODUCTION}

The type of channel pattern is the most significant index of the hydrological regime of a river (Allen 1970). The changing relations between particular elements of the hydrological regime such as discharge, water state, flow velocity, water temperature, ice cover and sediment transport (Dynowska 1971) influence the balance between erosional and accumulation processes. Generally, five main types of channel development are distinguished: straight, meandering, braided, anastomo- sing and wandering rivers (Miall 1996; Zieliński 1998). In the Polish Lowlands the most common types are meandering and braided rivers. Multi-channel river reaches defined as anastomosing rivers (Gradziński et al. 2003) occur in Poland in polygenic valley reaches, which often represent adapted melt-out basins after overflow lakes (Falkowski 1975). The presence of straight rivers is almost always linked with the character of the channel basement (Twindale 2004). Such rivers occur within the outcrops of rocks resistant to erosion, which form linear tectonic structures. In the Polish Lowland, short reaches of such rivers can be encountered near escarpments of moraine plateaus eroded by the rivers.

In the history of river valleys in the Polish Lowlands, climate was the main factor influencing the specific hydrological river regime and thus the type of channel. Climatic changes that took place in the terminal Pleistocene and the Holocene resulted in the creation of river terraces during the evolution of present-day rivers. During the Last Glaciation, for a relatively short time the Scandinavian ice-sheet twice (Mojski 2005) covered northern and western Poland. In the ice-free area the hydrological regime of 
the rivers was influenced by permafrost (Jahn 1970) and lack of dense vegetation cover. At low retention of the catchment basin, surface runoff played a significant role in the water balance. It supplied considerable amounts of sediment from the slopes to the channels. Thus, braided rivers overloaded with sediment functioned in the Polish Lowlands (Zieliński 1993; Mojski 2005). They often filled the rock-cut benches of the present-day valleys that developed in the Eemian Interglacial, forming surfaces of the upper terraces. The Pleistocene/Holocene warming resulted in dense vegetation within the drainage basin. Increase of surface retention caused leveling of flow with time and evolution of the river systems towards meandering rivers. The rivers incised into the surface of Pleistocene upper terraces forming flood terraces (Falkowski 1975; Kozarski, Rotnicki 1977; Mycielska-Dowgiałło 1978; Wiśniewski 1987; Florek 1991; Blum and Tornqvist 2000; Leigh et al. 2004).

About 6000 years BP, the hydrological regime of rivers in the Polish Lowlands began to be influenced by human activity, whenforestfiresandclearancewereapplied to gain arable ground. Such activities caused a subsequent change in the hydrological regime of the rivers, manifested by increased surface runoff and sediment supply (Falkowski 1975; Mycielska-Dowgiałło 1978; Starkel 1983). The present-day rivers of the Polish Lowlands, characterized by uneven flow (Starkel 1994) typically have braided channels, and the process of their transformation under human influence is referred to running wild (Falkowski 1975). The flood plain adjacent to the channel formed in such processes is known as the present- -day terrace (Falkowski 1975, 1990; Starkel 1983). Changes in the river regime are reflected in traces of channel migration that may be observed in particular accumulation horizons (terraces) of river valleys in the Polish Lowlands. They are particularly well-recognizable on aerial (Falkowski 1975; Szumański 1986) and satellite photographs. A thorough characteristic of the influence of human activity on the volume of sediment transported by rivers in the world was presented by Walling (2006).

According to Wolman, Miller (1960), Leopold et al. (1964), and Dury (1980), the character of channel processes is more significantly influenced by long-term, medium-scale phenomena and not extreme incidents. However, during flood-water some rivers may significantly transform the valley floor; as a result these transformations considerably influence fluvial processes that take place during long-term medium- and low-water states. The significance of high-water states in the morphology of present-day river valleys in the Polish Lowlands is marked by the formation of the present-day terrace due to the activity of flood-water. Its surface usually lies above other parts of the flood terrace. Accumulation of fine-grained sediments of the flood facies deposited from suspension is much slower than aggradation in the near-channel zone, where coarser material is deposited through decantation from flood-water.

The depth of the channel of present-day rivers increases during flooding. After the flood wave moves downriver, the channel is filled with the transported sediment as the transporting force of the river decreases. In the Middle Vistula River channel, such changes of the eleva- 
tion of the channel floor between highand medium-water may exceed $10 \mathrm{~m}$ (Falkowski 2006). During flooding, the basement of the present-day alluvia may be exposed, particularly in places where its top lies at relatively shallow depths. In such places the alluvial basement is built of soils more resistant to erosion. The morphology of their top surface may therefore influence the pattern of the river's main course, and thus the processes of erosion and accumulation within the channel and the flood-plain (Falkowski 2007a, b). Twindale (2004) pointed out the relation of the river valley basement on the course of present-day channel processes.

In regulated reaches the influence of the alluvial basement is often more significant than in the natural reaches. Narrowing of the flood-water channel by flood embankments increases the depth of flood-water erosion. In such places the influence of morphology of the resistant basement on the river course concentration results often in damage of regulation constructions and flood embankments (Falkowski 2007a, b).

A trend to increase differences between extreme flows is presently evident in the hydrological regime of rivers in the Polish Lowlands (Ozga-Zielińska 1997). The influence of the alluvial basement on the course of channel processes, which during meander formation was rather low (due to balanced flow), is much more significant presently due to increased depth of flood-water activity. Features of channel morphology that are indexes of a particular river regime and indicate the specific dynamics of erosional and accumulation processes, are increasingly dependent on the geological setting of the channel zone, particularly in reaches where the flood-water channel width is restricted by flood embankments.

\section{AIM AND METHODS OF STUDIES}

The studies carried out in the Pilica River valley between Inowłódz and Domaniewice (Fig. 1) were focused on determi-

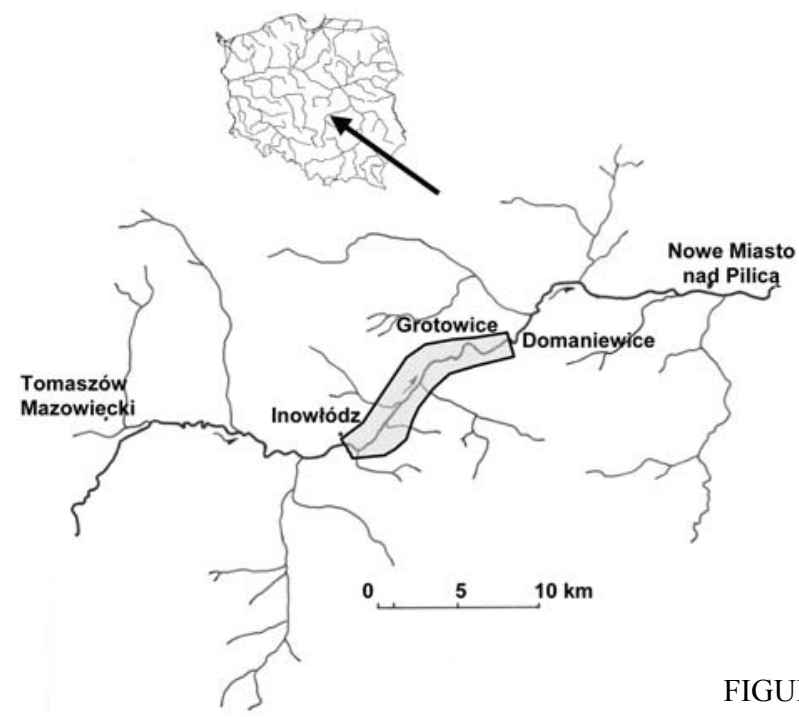

FIGURE 1. Location of study area 
ning the relation of the channel zone as well as floodplain morphology (contemporary and Holocene channels pattern) with the morphology and lithology of the alluvial basement. The channel pattern is connected with a specific variability of alluvial soil properties (Myślińska 1984; Kraużlis et al. 2003). Morphogenetic units corresponding to particular stages of the fluvial setting evolution (reflected in the channel pattern) are often the basis of units applied in documenting the geological-engineering conditions of river valleys (Falkowski 1990; Gilvear 1999).

The studied reach of the Pilica River valley incises into a fragment of a plateau with a mature, denudation morphology, developed since the end of the Middle Polish Glaciations. The rock-cut bench of the valley was formed partly in Middle Jurassic rocks and partly in glaciogenic deposits (Kłoda 1993).

The study included geomorphological analysis of the terrace surface based on aerial photographs. Surfaces of the valley floors, as well as geological drillings that document the surface of the flood-terrace and the channels of the studied rivers were also analyzed. Soil analysis as well as sedimentological and pollen analysis of the alluvial sediments were conducted. The studies were made in the frame of project no 2P04E 06929 Significance of morphogenetic factors in the development of habitat variability in selected reaches of river valleys in the Polish Lowlands, financed by the Ministry of Science and Higher Education of Poland.

\section{RESULTS}

The analyzed fragment of the Pilica valley is developed in Middle Jurassic siliceous sandstones and in various Pleistocene deposits (Figs 2, 3). Locally the sandstones crop out in an embankment of a plateau adjacent to the valley (Kłoda 1993). Above them occur medium and coarse sands with gravel, considered as Pleistocene alluvia from the Eemian Interglacial and the Vistulian Glaciation. They compose also the upper terraces in the valley (Kłoda 1993).

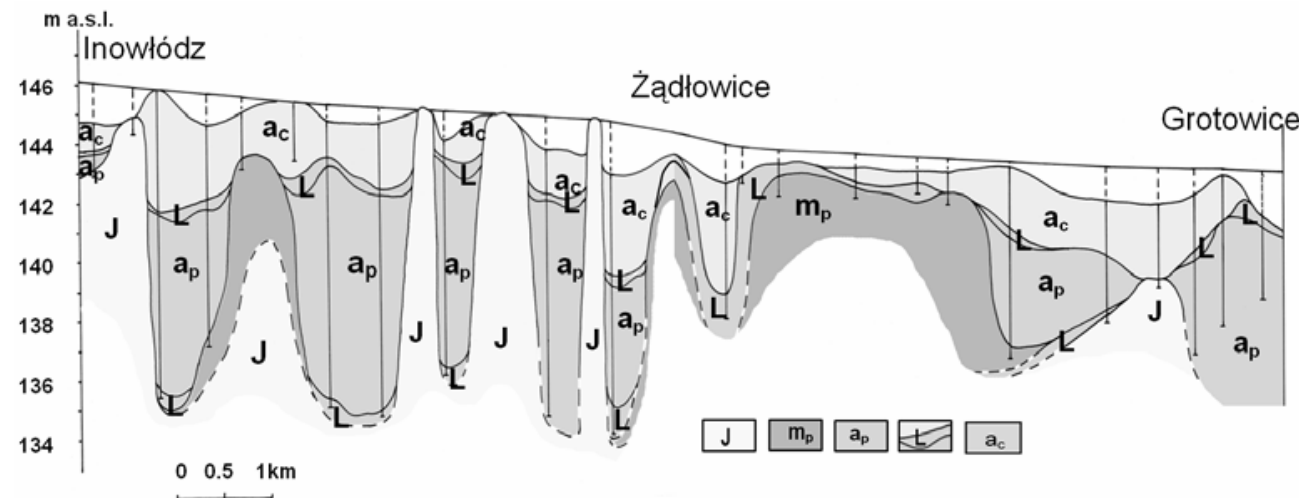

FIGURE 2. Schematic longitudinal geological cross-section through the Pilica River channel zone between Inowłódz and Grotowice; $\mathrm{J}$ - Jurassic sandstones, $\mathrm{m}_{\mathrm{p}}-$ moraine deposits (Pleistocene), $\mathrm{a}_{\mathrm{p}}-$ alluvial sands and gravels (Pleistocene), $\mathrm{a}_{\mathrm{c}}$ - channel facies alluvia of contemporary river, $\mathrm{L}$ - residual lag 


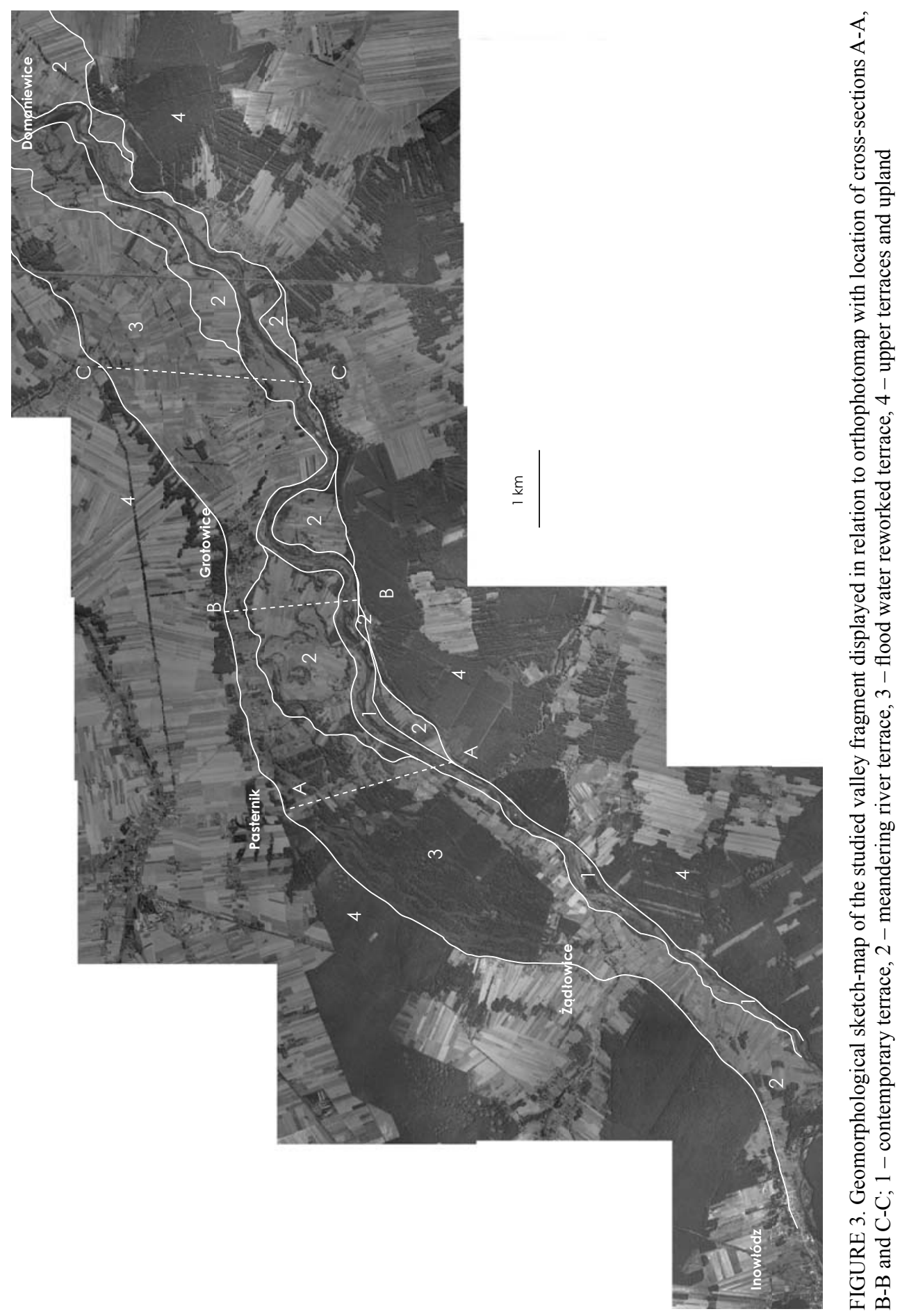


Above the Pleistocene deposits, on a bed of gravel-pebble lag occur deposits representing the flood terrace of the Holocene Pilica River (Figs 4, 5, 6). They are composed of a part formed by a meandering river and a part formed presently by a braided (wild) river.

The present-day terrace (flood-water channel) bears morphological features of a braided river setting (Fig. 3). The channel is shallow, rarely exceeding depths over $1.5 \mathrm{~m}$ at medium-water. Numerous longitudinal islands and shoals dividing the main course into branches are present in the channel. The braided character is confirmed by sedimentological analysis of the present-day alluvia (Falkowski, Górka 2009).

In the studied reach of the Pilica channel floor crop out deposits of the alluvial basement that are resistant to erosion (Fig. 2). They include Jurassic sandstones, as

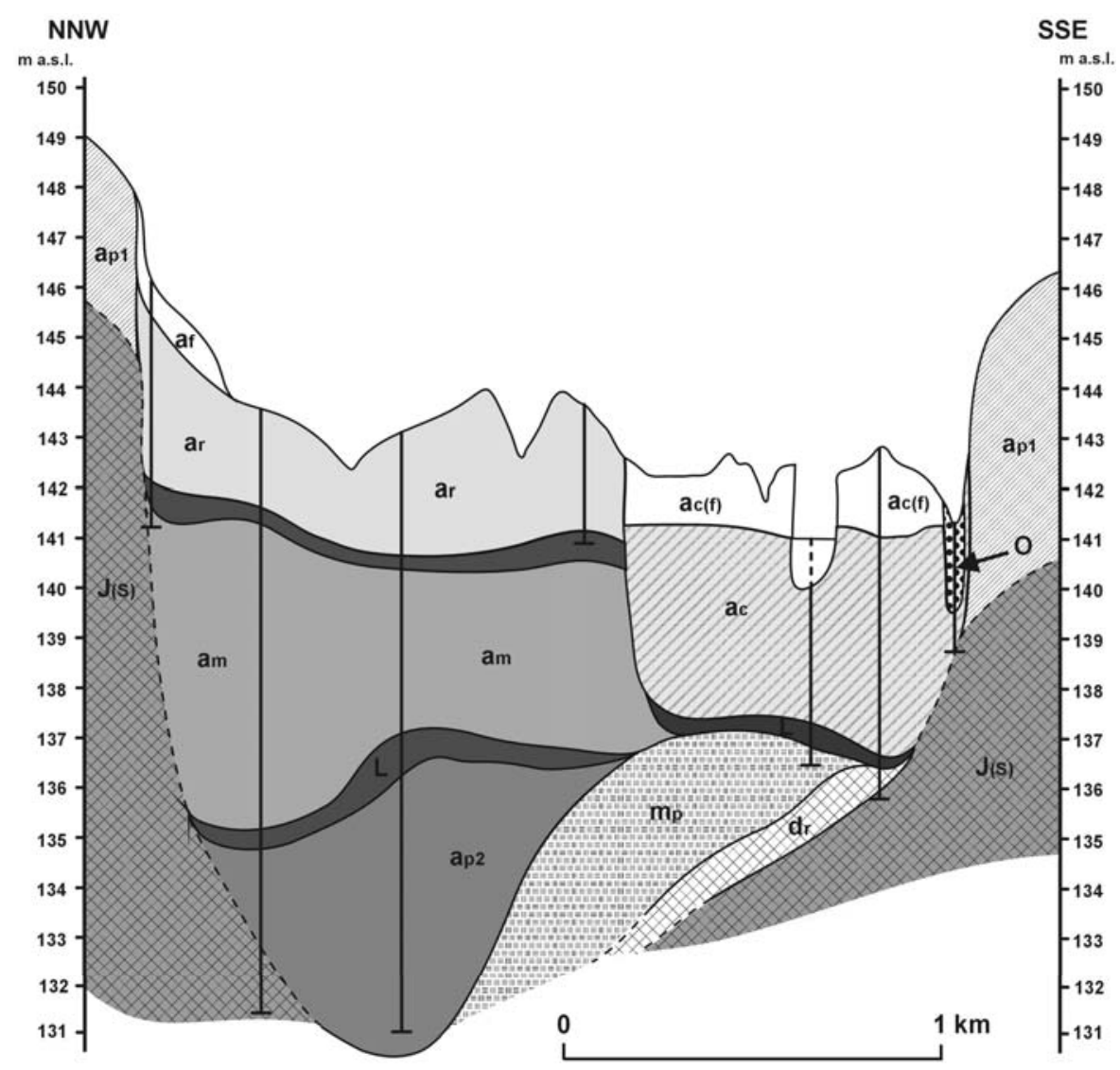

FIGURE 4. Transverse geological cross-section A-A through the flood terrace of the Pilica River (location on Fig. 3: explanations on Fig. 4); $\mathrm{J}_{(\mathrm{S})}$ - Jurassic sandstones, $\mathrm{dr}$ - decomposed rock, $\mathrm{m}_{\mathrm{p}}-$ moraine deposits (Pleistocene), $\mathrm{a}_{\mathrm{p} 2}, \mathrm{a}_{\mathrm{p} 1}$ - alluvial sands and gravels (Pleistocene), $\mathrm{a}_{\mathrm{m}}$ - channel facies alluvia of meandering river (Holocene), $a_{r}-$ reworked alluvia (Holocene), $a_{c}-$ channel facies alluvia of contemporary river, $\mathrm{a}_{\mathrm{c}(\mathrm{f})}-$ flood deposits of contemporary river, $\mathrm{o}-$ organic deposits, $\mathrm{a}_{\mathrm{f}}-$ alluvial fan, $\mathrm{L}-$ residual lag 


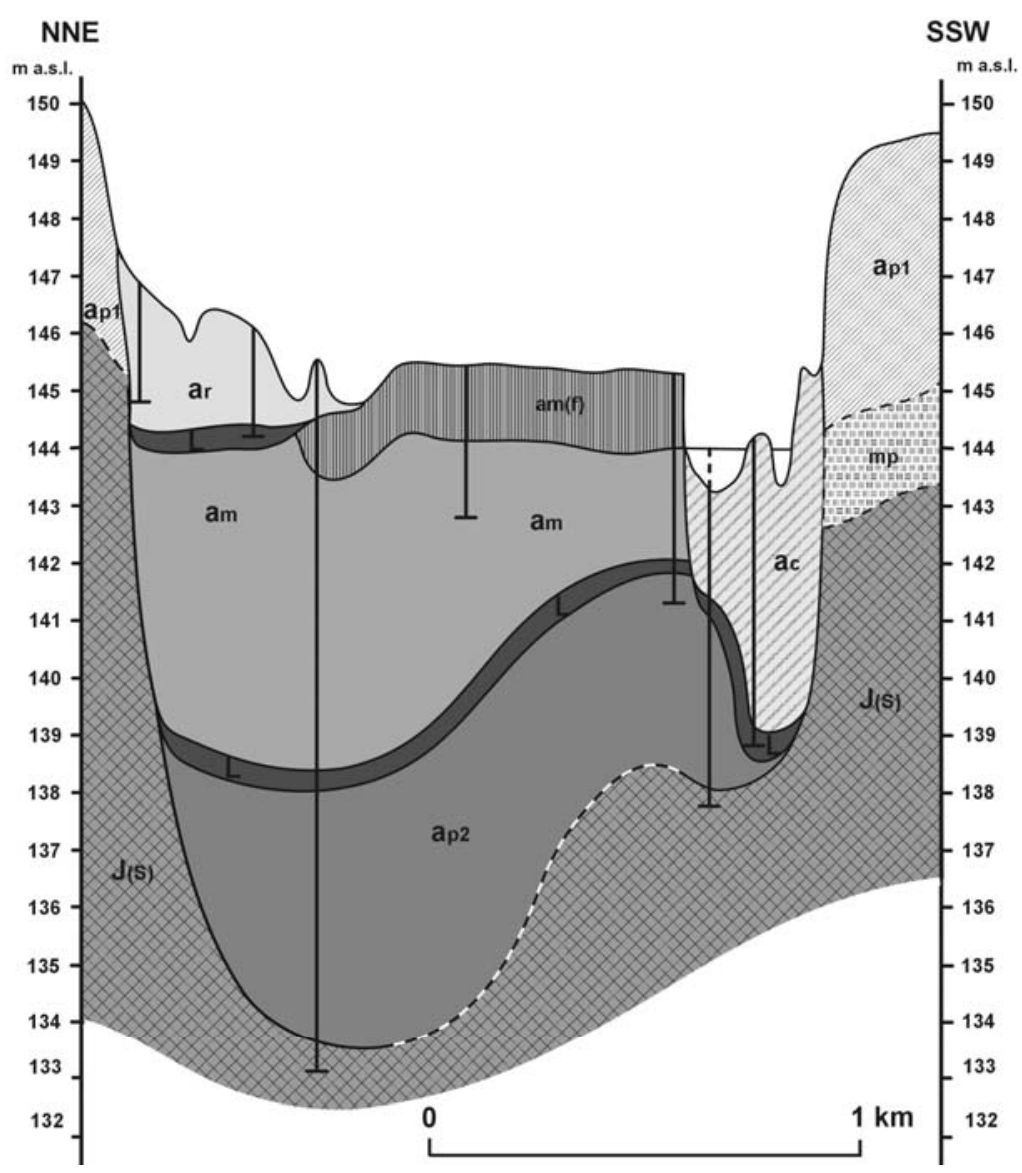

FIGURE 5. Transverse geological cross-section B-B through the flood terrace of the Pilica River (location on Fig. 3; explanations on Fig. 4)

well as moraine and ice-dammed deposits. Residual lags are common, composed of pebbles and cobbles. They typically lie on exposed glacial till. Deposits resistant to erosion form stabilizing protrusions in the river profile. Some of them are covered by thin channel alluvia. Between the protrusions the thickness of channel alluvia may reach 7-8 $\mathrm{m}$.

The remaining part of the flood terrace adjoining the present-day terrace bears traces of meandering processes only in the Pasternik and Grotowice area (Fig. 3).
These traces are not, however, evidence of lateral migration of the channel as in the case of other rivers in the Polish Lowlands (Vistula River valley - Falkowski 1975; Prosna River valley - Kozarski, Rotnicki 1977; San River valley Szumański 1986). The only evidence of meandering of the Pilica River is arch-like ox-bow lakes on the terrace surface. The thickness of the channel facies building this form reaches c. 5-6 m (Figs $4,5,6)$. Deposits include medium sands and medium sands with gravel. The top 


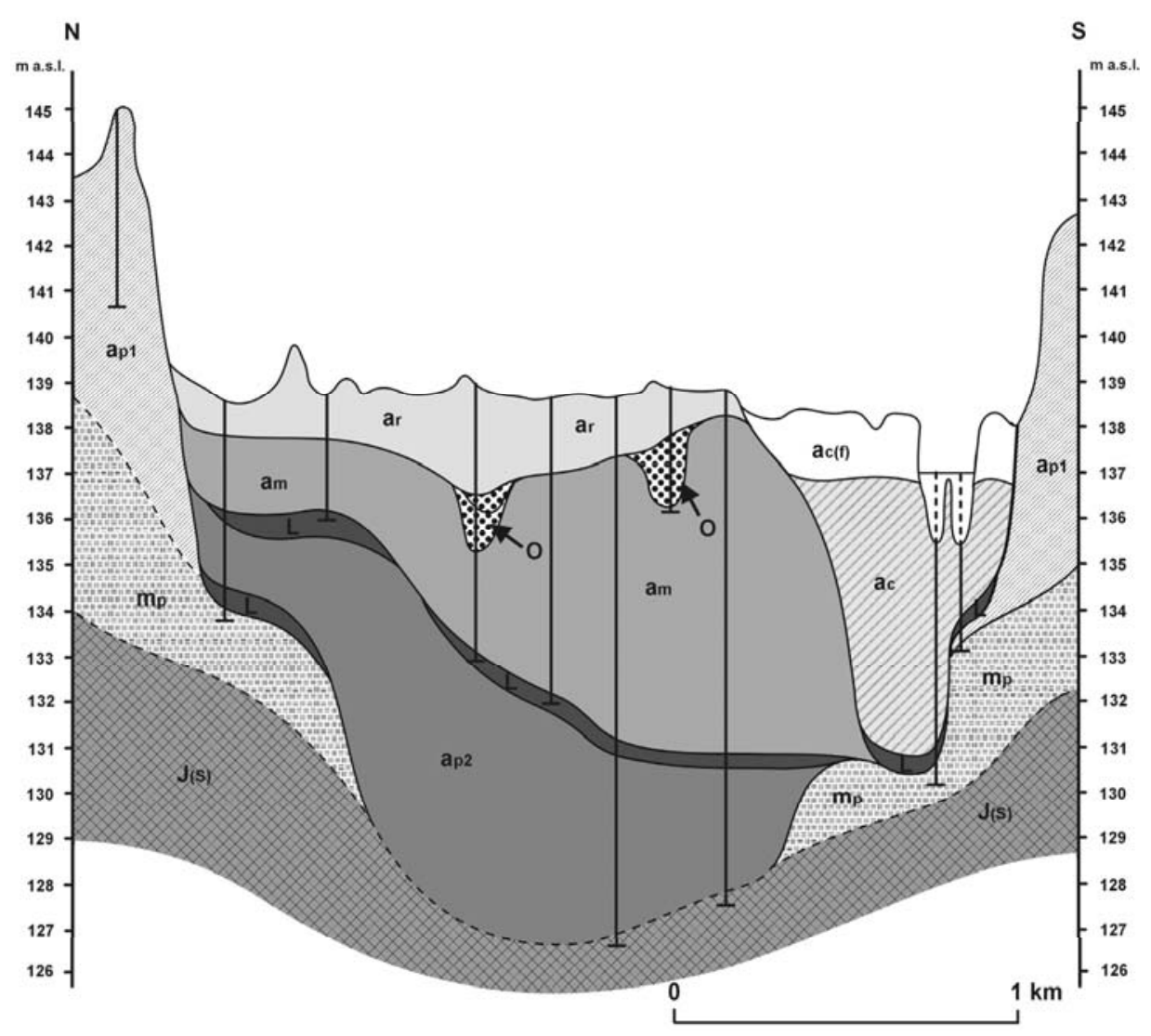

FIGURE 6. Transverse geological cross-section C-C through the flood terrace of the Pilica River (location on Fig. 3; explanations on Fig. 4)

part of the meandering river succession composed of flood facies differs from the flood facies of other rivers in the Polish Lowlands (Myślińska 1984). They lack cohesive deposits and are dominated by silty and fine sands with humus. Very rare are thin intercalations of clay and silt and organic muds. As show by pollen analysis, organic deposits from this part of the succession were redeposited in modern times.

The remaining part of the studied surface bears traces of transformation by flood-water. Between Żądłowice and Pas- ternik (Fig. 3) the terrace surface contains numerous longitudinal mid-channel sand bars separated by high-sinuosity chute channels. Differences in elevation on the surface reach occasionally $2 \mathrm{~m}$. The surface is covered by c. $3 \mathrm{~m}$ thick succession comprising medium sands with gravel and locally fine and silty sands. Residual lag composed of gravels and pebbles occurs in its base (Figs 4, 5).

Downriver from Grotowice, the surface of the valley floor was also transformed by flood-water (Fig. 3). Traces of meandering are not preserved here. On 
aerial photographs are visible traces of chute channels with similar sinuosity as between Żądłowice and Pasternik. The surface is, however, flat and devoid of distinct accumulation forms. Similarly as in the Żąłowice area, the basement is composed of fine and silty sands; residual lag was not noted in their base (Figs 5, 6).

\section{DISCUSSION}

The studies show that the present-day morphogenesis of the Pilica River in the analyzed reach depended on the alluvial basement. Protrusions occurring in the valley channel, composed of deposits resistant to erosion, such as sandstones, and moraine and ice-dammed deposits covered by residual lag stabilize the longitudinal profile of the channel and deep erosion. Studies of the channel zone showed the presence of exposures with organic soils, mainly peats, in reaches containing protrusions of the alluvial basement. Pollen analysis of these deposits indicates their Holocene age. The stabilizing role of the rock benches protects these deposits against erosion. Evorsion does not take place in these localities.

Floods that occur in the Pilica River valley in the studied reach are rather rare and of low magnitude due to the presence of an artificial Sulejów water reservoir located c. $30 \mathrm{~km}$ upriver. However, even before the reservoir was built, erosional deepening of the channel did not take place in the bench zones. The overflowing water was transported over the terrace surface, and traces of this process are the network of erosional flood-water channels on the surface of the present-day terrace. The braided pattern of the channel is thus partly the effect of restricted erosion in this part of the valley. During the Holocene climatic optimum, when Pilica was a meandering river, the alluvial basement did not considerably influence the flood-water flow, which is the result of hydrological regime, particularly flow balance.

The most significant influence of the morphology of the flood terrace has ice-jam water. Zones of the basement protrusions were probably places where ice-jams generated. The link between the occurrences of deposits resistant to erosion in the basement with the frequency of ice-jams was determined in the Middle Vistula valley (Falkowski, Popek 2000).

Overflowing waters generated due to ice-jams upriver from Żądłowice probably destroyed a fragment of the upper terrace, transforming at the same time the surface of the terrace formed by meandering the Pilica River. This is evidenced by a residual bed located at the depth of 2-3 m. Sediment transported by flood-water formed the morphology of the area between Żądłowice and Pasternik, removing or burying traces of meandering. Downriver of Grotowice, the flood-water did not carry such quantities of sediment. The top part of the alluvial succession of the meandering river was transformed, but a residual layer was not formed. Only the uppermost parts of the Holocene succession (fine-grained flood facies) were subject to reworking. Buried traces of meanders filled with organic soils were determined only in the downriver part of the analyzed reach.

Despite the lack of regulation structures (in the analyzed reach the Pilica River is not regulated), strangely enough the present-day river has chosen a zone 
to the right of the valley axis for its flow. Here occur protrusions of the alluvial basement composed of deposits resistant to erosion. Cross-sections indicate that to the left of the valley axis the top of the alluvial basement lies at lower depths.

\section{CONCLUSIONS}

A crucial factor influencing the course of present-day channel processes in the analyzed reach of the Pilica River, including its braided character, is the alluvial basement.

Influence of the basement may reach far beyond the channel zone, thus the analysis of channel pattern changes observed on the entire surface of the flood terrace (e.g. in the pattern of photolineaments on aerial or satellite photographs) may indicate the channel state and be the base of predictions on the evolution of channel processes.

The author's experience with selected reaches of other rivers in the Polish Lowlands (e.g. the Bug, the Narew, the lower Oder, the middle and lower Vistula rivers) evidence that influence of the basement is favoured by the lack of balanced flow in the river and the resulting increase of flood-water erosion (reworking of alluvial sediments). The observed trend of increasing difference between the extreme states of the lowland rivers should attract significant attention to such forms.

\section{REFERENCES}

ALLEN J.R.L., 1970: Physical processes of sedimentation; George Allen and Unwin LTD, London.

BLUM M.D., TORNQUIST T.E., 2000: Fluvial response to climate and sea-level change, a review and look forward, Supl. Sediment. 47, $2-48$.

DURY G.H., 1980: Peak Flows, Low Flows, and Aspects of Geomorphic Dominance, w: K.J. Gregory (red.) River Channel Changes, John Wiley \& Sons, 61-74.

DYNOWSKA I., 1971: Types of river regimes In Poland; Zeszyty Naukowe U.J. CCLXVIII, Prace Geograficzne, z. 28, ss. 150 (In Polish).

FALKOWSKI E., 1975: Variability of channel processes of lowland rivers in Poland and changes of Valley floors Turing Holocene; Biuletyn Geologiczny Uniwersytetu Warszawskiego 19, 45-78.

FALKOWSKI E., 1990: Morphogenetic classification of river valleys developing in formerly glaciated areas for needs of mathematical and physical modeling in hydro technical projects. Geographia Polonica vol. 58, 55-67.

FALKOWSKI T., 2006: Factors of natural stability of the Middle Vistula River channel zonej; Wydawnictwo SGGW; Rozprawy Naukowe i Monografie, ss. 128 (In Polish).

FALKOWSKI T., 2007a: Geomorphological analysis of a The Vistula River valley in evaluating the safety of regulation structures; Acta Geologica Polonica Vol 57 (3) 377-390.

FALKOWSKI T., 2007b: Alluvial bottom geology inferred as a factor controlling channel flow along the Middle Vistula River, Poland; Geological Quarterly 51 (1), 91-102.

FALKOWSKI T., GÓRKA M., 2009: Sedimentary structures and their usefulness in the Polish Lowland river valleys management; Nauka Przyroda Technika, Wydawnictwo Uniwersytetu Przyrodniczego w Poznaniu; Melioracje i Inżynieria Środowiska, tom 3, zeszyt 3, \# 81 (In Polish).

FALKOWSKI T., POPEK Z., 2000: Zones of ice-jams formation on the Middle Vistula River reach in relation to variable of river valley morphology; Annals of WAU, Land Reclamation No 30, 77-90.

FLOREK W., 1991: Postglacial development of River Valley in the Middle part of the northern slope of Pomerania, Wyższa Szkoła Pedagogiczna, Słupsk, 142 pp. (In Polish).

GILVEAR D.J., 1999: Fluvial geomorphology and river engineering: future roles utilizing a fluvial hydrosystems framework; Gemorpho$\operatorname{logy} 31$, Elsevier, 229-245. 
GRADZIŃSKI R., BARYŁA J., DOKTOR M., GMUR D., GRADZIŃSKI M., KĘDZIOR A., PASZKOWSKI M., SOJA R., ZIELIŃSKI T., ŻUREK S., 2003: Vegetation-controlled modern anastomosing system of the upper Narew River (NE Poland) and its sediments; Sedimentary Geology 157, Elsevier, 253-276.

JAHN A., 1970: Problems of the Periglacial Zone. PWN, Warszawa $186 \mathrm{pp}$.

KŁODA P., 1993; Explanations to the Detailed Geological Map of Poland, scale 1:50 000, Rzeczyca sheet; Państwowy Instytut Geologiczny; Warszawa (In Polish).

KOZARSKI S., ROTNICKI K., 1977: Valley floors and changes of river channel patterns in the North Polish Plain during the Late Wurm and Holoceneł Quaestiones Geographicae 4, 51-93.

KRAUŻLIS K., LASKOWSKI K., WÓJCIK E., 2003: Variability of Engineering geological parameters in flood facies sediments; Geological Quarterly, 47, Państwowy Instytut Geologiczny Warszawa, 63-68.

LEIGH D.S., SRIVASTOVA P., BROOK G.A., 2004: Late Pleistocene braided rivers of the Atlantic Coastal Plain, USA; Quaternary Science Reviews 23, Pergamon, 65-84.

LEOPOLD L.B., WOLMAN M.G., MILLER J.P., 1964: Fluvial Processes in Geomorphology; Freeman \& Company, San Francisco.

MIALL A.D., 1996: The Geology of Fluvial Deposits. Sedimentary Facies, Basin Analysis and Petroleum Geology, Springer, 1-582.

MOJSKI J.E., 2005: Area of Poland in Quaternary. Outline of morphogenesis; Państwowy Instytut Geologiczny, Warszawa (In Polish).

MYCIELSKA-DOWGIAŁŁO E., 1978: Development of the fluvial relief in the northern part of the Sandomierz basin in the approach of sedimentological analyses; Rozprawy Uniwersytetu Warszawskiego, pp 120 (In Polish).

MYŚLIŃSKA E., 1984: Variability of engineering geological parameters in flood facies sediments; Kwartalnik Geologiczny 28, 143-162 (In Polish).

OZGA-ZIELIŃSKA M., 1997: The Reed of determining the Maxima reliable high-water levels caused by maximal reliable rainfall for Polish rivers. Forum naukowo-techniczne - POWÓDŹ 1997, IMGW Warszawa, tom 2, 1-10 (In Polish).
STARKEL L., 1983: The reflection of hydrologic changes in fluvial environment of the temperate zone during the last 15000 years, in: Gregory J. (ed.) Background to Paleohydrology, J. Wiley, Chichester, 213-234.

STARKEL L., 1994: Frequency of floods during the Holocene in the Upper Vistula Basin; Studia Geomorphologica Carpatho-Balcanica 27-28, 3-13.

SZUMAŃSKI A., 1986: Post Glacial evolution and mechanism of transformation of a floor of a Lower San. Valley; Zeszyty Naukowe AGH, Geologia, t. 12, z. 1, 5-92 (In Polish).

TWINDALE C.R., 2004: River pattern and their meaning; Earth-Science Reviews 67, Elsevier, 159-218.

WALLING D.E., 2006: Human impact on land-ocean sediment transfer by the word's rivers; Gepmorphology 79, 196-216.

WIŚNIEWSKI E., 1987: The evolution of the Vistula river valley between Warsaw and Płock Bassin during last 15000 years, in: Starkel L.: Evolution of Vistula river valley during the last 15000 years, Part II, Geographical Studies Special Issue 4, IGiPZ PAN, 171-187.

WOLMAN M.G., MILLER J.P., 1960: Magnitude and frequency of forces in geomorphic processes; J. Geol. 68, 54-74.

ZIELIŃSKI T., 1993: Sandurs of NE Poland - sediments and deposition conditions; Prace Naukowe Uniwersytetu Śląskiego, 1398, 1-97 (In Polish).

ZIELIŃSKI T., 1998: Lithofacial identification of alluvial sediments, in: Mycielska-Dowgiałło E. (red.) Sedimentological and postsedimentological structures in Quaternary sediments and their value for interpretation, Wydział Geografii i Studiów Regionalnych UW, 193-260 (In Polish).

Streszczenie: Wplyw podloża aluwiów na typ rozwinięcia koryta rzecznego na przykładzie wybranego odcinka Pilicy. Typ rozwinięcia koryta rzecznego jest wskaźnikiem stanu środowiska fluwialnego i reżimu hydrologicznego szczególnie dojrzałych rzek nizinnych. Badanie prowadzone w dolinie Pilicy na odcinku między Inowłodzem a Domaniewicami (grant nr 2P04E 06929 MNiSW) wykazały, że wpływ na morfologię i litologię zarówno strefy korytowej 
współczesnej Pilicy, jak i formowanej w holocenie równi zalewowej ma budowa geologiczna podłoża doliny, a szczególnie odsłaniające się w korycie kulminacje jego powierzchni zbudowane z gruntów o większej odporności na erozję. Warunkowane obecnością trudno rozmywalnych progów przepływy wezbraniowe przemodelowały powierzchnię tarasu zalewowego, a w znacznej części analizowanego odcinka zatarły także ślady holoceńskiej ewolucji rzeki. Na wielu odcinkach koryta warunkują także współcześnie jego morfologię.

MS. received April 2010

Author's address:

Katedra Geoinżynierii SGGW

02-776 Warszawa, ul. Nowoursynowska 159

Poland

e-mail: tomasz_falkowski@o2.pl 